\title{
Clinical Study of Pancytopenia
}

\author{
Vaidya $M^{1}$, Gupta V. $A^{2}$, Khandagale $S . K^{3}$ \\ ${ }^{1}$ Dr Meghna Vaidya, Associate Professor, ${ }^{2}$ Dr Vishal Anand Gupta, Assistant Professor, ${ }^{3}$ Dr Shrikrushna Khandagale, \\ Resident, all authors are attached with Department of Medicine, Seth GS Medical College and KEM Hospital, Mumbai., \\ India.
}

Address for Correspondence: Dr Meghna Vaidya, Email: meghnavaidya6@yahoo.com4

\begin{abstract}
Introduction: Pancytopenia is a common and alarming condition encountered by clinicians. We had studied the clinical presentation, laboratory investigations and various etiologies of Pancytopenia. Material and Methods: Study was carried out in a tertiary care centre in western India. A total of 102 patients fulfilling the criteria of pancytopenia were enrolled and studied. Results and conclusion: Megaloblastic anemia was commonest cause of pancytopenia. Easy fatigability and pallor were commonest symptoms and signs respectively. Maximum bleeding manifestations were seen in aplastic anemia and Myelodysplastic syndrome.
\end{abstract}

Keyword: Pancytopenia, Bone marrow, Megaloblastic anemia

\section{Introduction}

A wide spectrum of primary and secondary disorders affect the bone marrow and may manifest with pancytopenia [1]. Pancytopenia could present with normocellular, hypocellular or hypercelluar marrow as seen in various conditions like infections, toxins, malignant infiltration, dysplasia, peripheral sequestration of blood cells, etc.

Pancytopenia can present with a wide spectrum of symptoms ranging from fatigue to life threatening bleeding manifestations depending on the underlying etiology and severity of pancytopenia. The study aims at describing the clinical signs and symptoms, lab investigation and etiologies in cases of pancytopenia.

Most of studies in India used following values for diagnosis of Pancytopenia [2,3]

- Hemoglobin <10 gm\%

- Total leukocyte count less than $3500 / \mathrm{cmm}$

- Platelet count less than $1,00,000 / \mathrm{cmm}$

Above mentioned values of hemoglobin, total leukocyte count and platelet counts are used as diagnostic criteria for pancytopenia in our study.

Manuscript received $25^{\text {th }}$ July 2016

Reviewed: $10^{\text {th }}$ August 2016

Author Corrected: $20^{\text {th }}$ August 2016

Accepted for Publication $3^{\text {rd }}$ September 2016
Study Design: The one year prospective observational study was done in a premier tertiary care teaching hospital.

\section{Inclusion Crieteria}

- Indoor patients with pancytopenia (Hemoglobin $<10$ gm\%, Total leukocyte count less than $3500 / \mathrm{cmm}$, Platelet count less than $1,00,000 / \mathrm{cmm}$ )

- Age more than 12 years.

- Willing to give consent.

\section{Exclusion Crieteria}

- Patients on Chemotherapy

Individual patients were asked detail history about symptoms, past history, personal habits. Detailed physical examination including general and systemic examination werecarried out and entered in the proforma.

The routine and specific investigation done at discretion of treating physician was noted. Prognosis in terms of in-hospital mortality was assessed.

Unpaired $\mathrm{T}$ test and other relevant statistical tests were applied for statistical analysis. 


\section{Result and Analysis}

Our study comprised of 102 patients ranging from 13 years to 65 years of age, youngest being 13 years and oldest 65 years old. Maximum patients of pancytopenia were in between 21 -30 years of age 33.3\% (34/102) followed by 31-40 year $30.4 \%$ (31/102), 12- 20 year age group had $13.7 \%$ (14/102) and only $2.9 \%(3 / 102)$ were having age more than 60 year. Mean age in our study was 32.8 years.

Distribution of etiology for pancytopenia in our study is given in Table 01.

Table 1: Distribution of cases of pancytopenia according to etiology.

\begin{tabular}{|c|c|c|}
\hline Disgnosis & No. of Cases & Percent \\
\hline ALL & 2 & 2.0 \\
\hline AML & 9 & 2.8 \\
\hline Aplastic Anemia & 20 & 1.0 \\
\hline CLD & 3 & 1.0 \\
\hline Dengue & 1 & 1.0 \\
\hline Enteric fever & 1 & 1.0 \\
\hline HCV & 1 & 6.9 \\
\hline Disseminated tuberculosis & 1 & 5.9 \\
\hline Malaria & 7 & 43.1 \\
\hline MDS & 6 & 1.0 \\
\hline Megaloblastic anemia & 44 & 1.0 \\
\hline Multiple myeloma & 1 & 1.0 \\
\hline NHL & 1 & 3.9 \\
\hline RA & 1 & $\mathbf{1 0 0 . 0}$ \\
\hline SLE & 4 & $\mathbf{1 0 2}$ \\
\hline Total & & \\
\hline
\end{tabular}

Megaloblastic anemia was the most common etiology of pancytopenia seen in 44 out of 102 patients (43.1\%) in our study followed by aplastic anemia (19.6\%),

Patients with Dengue with Hemophagocytic Lymphocytosis (HLH), Enteric fever, Hepatitis C Virus (HCV) related hepatitis, disseminated tuberculosis, multiple myeloma, Non Hodgkin Lymphoma (NHL), Rheumatoid Arthritis (RA) [Methotrexate induced] had pancytopenia in $1 \%$ of cases each.

In our study 3 patients had tuberculosis of which 2 had Ileocaecal tuberculosis who presented as megaloblastic anemia hence included in megaloblastic anemia, the third person had disseminated tuberculosis hence kept as a separate etiology. Amongst 3 Chronic Liver Disease (CLD) patients 2 had pancytopenia presumably due to hypersplenism and the third one had CLD secondary to hepatitis B and hepatitis C viral infections with chronic kidney disease.

Gender wise distribution of etiology is given in Table 2 .

Male preponderance was seen in Megaloblastic anemia, Acute Myeloid Leukemia, CLD, Multiple myeloma, disseminated tuberculosis.

Female cases were more than males in aplastic anemia and Myelodysplastic syndrome (MDS). Acute Lymphoblastic Leukemia (ALL) was equally seen in male and female patients; one patient each. Enteric fever, HCV related hepatitis, NHL, RA, SLE were seen only in female patients in our study. 
Table-2: Gender wise distribution of patient of pancytopenia as per etiology.

\begin{tabular}{|c|c|c|c|}
\hline Diagnosis & Female & Male & Total No \\
\hline ALL & 1 & 1 & 2 \\
\hline AML & 3 & 6 & 20 \\
\hline Aplastic Anemia & 11 & 9 & 1 \\
\hline CLD & 0 & 1 & 1 \\
\hline Dengue & 0 & 0 & 1 \\
\hline Enteric fever & 1 & 0 & 7 \\
\hline HCV & 1 & 1 & 6 \\
\hline Disseminated tuberculosis & 0 & 5 & 44 \\
\hline Malaria & 2 & 28 & 1 \\
\hline MDS & 5 & 1 & 1 \\
\hline Megaloblastic anemia & 16 & 0 & 1 \\
\hline Multiple myeloma & 1 & 0 & 4 \\
\hline NHL & 1 & 0 & 102 \\
\hline RA & 4 & 56 & \\
\hline SLE & 46 & & 1 \\
\hline
\end{tabular}

Table-3: Distribution of cases pancytopenia according to symptoms.

\begin{tabular}{|c|c|c|}
\hline Symptoms & Total & Percentage \\
\hline Easy fatigability & 100 & 98.0 \\
\hline Edema feet & 6 & 5.9 \\
\hline Fever & 34 & 93.3 \\
\hline Oral ulcer & 10 & 14.7 \\
\hline $\begin{array}{c}\text { Petechie bleeding gum other } \\
\text { bleeding manifestation }\end{array}$ & 15 & 63.7 \\
\hline Loss of appetite & 65 & $\mathrm{~s}$ \\
\hline
\end{tabular}

Commonest symptom in our study was easy fatiguability seen in $98 \%$, followed by loss of appetite in $63.7 \%$, fever in $33.3 \%$, bleeding in $14.7 \%$. Edema feet observed in least number of patients $(5.9 \%)$.

Table-4: Distribution of cases pancytopenia according to signs.

\begin{tabular}{|c|c|c|}
\hline Signs & Total & Percentage \\
\hline Fever & 36 & 35.29 \\
\hline Pallor & 100 & 13.73 \\
\hline Bleeding manifestation & 14 & 10.78 \\
\hline Knuckle pigmentation & 11 & 4.90 \\
\hline Lymphadenopathy & 5 & 4.90 \\
\hline Icterus & 5 & 5.88 \\
\hline Oral Candidiasis & 6 & 5.88 \\
\hline Sternal tenderness & 6 & 3.92 \\
\hline Hepatomegaly & 4 & 10.78 \\
\hline Splenomegaly & 11 & 10.2 \\
\hline Edema feet & 10 & \\
\hline
\end{tabular}


Commonest sign encountered in our study was pallor seen in 100 patients [98\%]. This was followed by fever in 36 patients i.e., $35.29 \%$, of these, 12 patients had an infectious disease, 9 patients had hematological malignancy, 7 had Aplastic anemia, 4 had an autoimmune disease, 3 had megaloblastic anemia and 1 had disseminated tuberculosis. Oral candidiasis was seen in $5.8 \%$ of patients, all of them had fever and had a hematological malignancy. Splenomegaly and knuckle pigmentation was seen in $10 \%$ of patients each. The least common sign was hepatomegaly seen in $3.9 \%$ patient [4/102]. Knuckle pigmentation was seen in 11 patients out of whom 10 patients had megaloblastic anemia.

Table-5: Distribution of number of patients according to laboratory parameters.

\begin{tabular}{|c|c|c|c|c|}
\hline Hb $($ gm\%) & $<\mathbf{5}$ & $\mathbf{5 - 7 . 5}$ & $\mathbf{> 7 . 5}$ & Total \\
\hline No of Cases & $35(34.3 \%)$ & $53(52 \%)$ & $14(13.7 \%)$ & $102(100 \%)$ \\
\hline WBC $(/ \mathbf{c m m})$ & $<\mathbf{1 5 0 0}$ & $\mathbf{1 5 0 0 - 2 5 0 0}$ & $\mathbf{> 2 5 0 0}$ & Total \\
\hline No of Cases & $27(26.5 \%)$ & $38(37.2 \%)$ & $37(36.3 \%)$ & $102(100 \%)$ \\
\hline Platelet $(/ \mathbf{c m m})$ & $<\mathbf{2 0 0 0}$ & $\mathbf{2 0 0 0 0 - 5 0 0 0 0}$ & $\mathbf{> 5 0 0 0 0}$ & Total \\
\hline No of cases & $26(25.5 \%)$ & $35(34.3 \%)$ & $41(40.2 \%)$ & $102(100 \%)$ \\
\hline
\end{tabular}

In our study maximum number of patients had Hemoglobin between $5-7.5 \mathrm{gm} \%$ [52\%], followed by $\mathrm{Hb}<5$ gm\% [34.3\%] and $\mathrm{Hb}>7.5 \mathrm{gm} \%$ in 13.7\%. Maximum number of patients had WBC between 1500-2500/cmm [37.2\%], followed by WBC $>2500 / \mathrm{cmm}$ [36.3\%], WBC <1500/cmm in 26.5\%. Maximum number of patients had platelet count > $50,000 / \mathrm{cmm}$ [40.2\%], followed by platelet count between 20,000 to $50,000 / \mathrm{cmm}$ in $34.3 \%$ and platelet count $<20,000$ in $25.5 \%$ of patients.

Patients with primary hematological spectrum of diseases [ N=40, ALL -2, AML -9, Aplastic anemia-20, MDS-6, NHL1, Multiple myeloma-1, HLH in dengue -1] $47.5 \%$ had Hemoglobin less than 5 gm $\%$ and $50 \%$ had Hemoglobin between 5-7.5 gm\% and only one patient of AML had Hemoglobin more than $7.5 \mathrm{gm} \%$.

In patients of Aplastic anemia hemoglobin $<5 \mathrm{gm} \%$ was seen in $45 \%$ and between $5-7.5 \mathrm{gm} \%$ was seen in $55 \%$ and none of them had $\mathrm{Hb}>7.5 \mathrm{gm} \%$. In megaloblastic anemia maximum number of patients, 54.4\% had Hemoglobin between 5$7.5 \mathrm{gm} \%$. Even though the number of patients of ALL and disseminated tuberculosis were low i.e. 2 and 1 respectively all had hemoglobin less than $5 \mathrm{gm} \%$

All patients having mortality had $\mathrm{Hb}<5 \mathrm{gm} \%$. On comparing mean $\mathrm{Hb}$ of expired group and survived group with mortality, there is significant mortality with low hemoglobin ( $\mathrm{p}$ value $<0.001$ by unpaired $\mathrm{t}$ test).

Patients of MDS had lowest mean platelet count i .e. 25000/cmm, followed by aplastic anemia i.e. 25750/cmm, ALL 28000 and AML 38778/cmm. Maximum mean platelet count was seen in CLD i.e. $71000 / \mathrm{cmm}$ and megaloblastic anemia $58864 / \mathrm{cmm}$.

Most common cause of megaloblastic anemia in our study was vegetarian diet [75\%] leading to deficiency of vitamin B12 and/or Folic acid. chronic alcoholism [13\%] was second common cause of megaloblastic anemia. Other causes were Ileocaecal tuberculosis $4.6 \%$ leading to Vitamin B12 malabsorption. Patients of pernicious anemia, HIV with megaloblastic anemia, HIV with alcoholic intake causing megaloblastic anemia formed $2.2 \%$ of the study group each. Mortality in patients with pancytopenia is shown in table 06 .

Table-6: Mortality in cases of pancytopenia.

\begin{tabular}{|c|c|c|}
\hline Outcome & No. of cases & Percentage (\%) \\
\hline Expired & 6 & 5.9 \\
\hline Survived & 96 & 94.1 \\
\hline Total & $\mathbf{1 0 2}$ & $\mathbf{1 0 0 . 0}$ \\
\hline
\end{tabular}


Table 06 Mortality in patients with pancytopenia: Out of 102 patients in our study 6 patients expired hence total mortality was 5.9\%. Among the 6 patients 3 belonged to aplastic anemia [3/6], followed by one each of patients having ALL, AML and MDS. Amongst patients with aplastic anemia mortality was seen in $15 \%$ of patients. Among patients ALL, AML and MDS mortality was seen in 50\%, 11\%, $16 \%$ of patients respectively.

\section{Discussion}

Pancytopenia is a common and serious hematological problem. The aetiology for pancytopenia varies widely depending on age and geographical distribution. Though extensive studies and guidelines are available for different etiologies like aplastic anemia and myelodysplastic anemia, guidelines and studies on pancytopenia are few.

The commonest cause of pancytopenia in our study was megaloblastic anemia. We found that megaloblastic anemia was also the commonest cause in many other Indian studies like Tilak et al [2], Khodke et al [3], Seema B et al [6], B N Gayathri et al [7], Doshi et al [8] Bhaskar B et al [9] as mentioned in table 07 below. In one study by Khanduri U, et al [10] out of 175 patients with megaloblastic anemia $62 \%$ of patients had pancytopenia. Megaloblastic anemia usually results from deficiency of Vitamin B12 or Folic acid or a deficiency in their metabolism [11].

Vitamin B12 is a water soluble vitamin with recommended daily requirement of 1-3 microgram (mcg) for adults [12]. Humans receive B12 exclusively from the diet. Meat is a good source of B12 with 10mcg/100 gm of weight. Other sources include egg yolk and fish. Dietary habits, taboos and poverty are responsible for majority of Vitamin B12 deficiency cases.

Vegetarians and vegans form a good number of Indian population reflecting high number of megaloblastic anemia in our study. Patients with severe B12 deficiency should receive parenteral $1 \mathrm{mg}$ of cobalamin daily for 1 week, $1 \mathrm{mg}$ twice weekly for one week thereafter followed by $1 \mathrm{mg}$ every week for 4 weeks. This is to be followed by $1 \mathrm{mg} / \mathrm{month}$ for life for malabsorption or lifelong $10 \mathrm{mg}$ orally for nutritional deficiency. In other Indian study conducted by Santra G et al [13] in West Bengal the commonest cause was Aplastic anemia [20.7\%] this could be explained by abundant sea food intake in West Bengal reducing the incidence of Vitamin B12 deficiency.

A Jain et al [14] reported hypersplenism as the commonest cause among 250 cases in southern Maharashtra owing to high cases of CLD in their study. In most studies conducted in western countries, aplastic anemia was the major cause of pancytopenia. On comparing international data: the International Agranulocytosis and Aplastic anemia study [4] aplastic anemia [52.7\%] was the major etiology while in the study conducted by Keisu et al [5] neoplastic diseases and radiation [32\%] were the commonest cause of pancytopenia, both studies were conducted in Israel and Europe.

Aplastic anemia seen in $19.6 \%$ of patients in our study was the second most common etiology. In other Indian studies like Santra G et al [13]. Doshi et al [8]. Bhaskar et al [9]. CLD [11.7\%], infectious diseases [20\%] and malaria [19\%] were the second most common causes respectively. In our study CLD, infectious diseases including malaria were $2.9 \%$ and $8.5 \%$ respectively though malaria is endemic in Mumbai. Aplastic anemia is charecterised by pancytopenia with a hypocellular marrow without any abnormal fibrosis or infiltrates.

Majority of the cases are idiopathic and the rest represent inherited or genetic bone marrow failure syndrome. It is important to rule out PNH and MDS in patients of aplastic anemia. Patients of aplastic anemia require supportive treatment like blood and platelet transfusion [15]. Immunosuppressive therapy is recommended for non-severe AA requiring treatment, treatment of severe or very severe AA not having matched hematopoietic stem cell donor or patients older than 50 years. Horse ATG and Cyclosporine are the preferred immunosuppressive drugs. Hematopoietic stem cell transplant should be considered in younger patients [15].

Hematological malignancies including AML, ALL, NHL and multiple myeloma were seen in 13 out of 102 cases. Infective etiologies were other important factors in our studies with malaria causing pancytopenia in 8 of the patients. Malaria can cause pancytopenia as a result of hemolysis, DIC, bone marrow necrosis, hemophagocytosis, impairment of marrow function, hypersplenism or direct bone marrow invasion by the parasite. Hamid et al. reported hypersplenism 
(28\%) and malaria (17.3\%) to be the two most common causes of pancytopenia contributing for more than $45 \%$ of cases in his study of 75 pancytopenia patients. [16]. Leishmaniasis constituted about $13.58 \%$ of total cases of pancytopenia in study by Dasgupta [17], similar results were seen from other studies from other parts of India, [18] however none of our patients had leishmaniasis. Dengue fever is another common infection causing pancytopenia, though it was seen in only one patient during our study, it will be interesting to study leucopenia and thrombocytopenia (Bicytopenia) as hemoconcentration is commonly encountered in Dengue fever [19].

Table-7

\begin{tabular}{|c|c|c|c|c|c|c|c|c|}
\hline $\begin{array}{l}\text { Sr. } \\
\text { No }\end{array}$ & Study / Year & $\begin{array}{l}\text { Coun } \\
\text { Try }\end{array}$ & $\begin{array}{l}\text { No. of } \\
\text { Cases }\end{array}$ & $\begin{array}{c}\text { Commonest } \\
\text { Cause }\end{array}$ & $\begin{array}{l}\text { Second } \\
\text { common } \\
\text { cause }\end{array}$ & $\begin{array}{c}\text { Most } \\
\text { common } \\
\text { presenting } \\
\text { symptom }\end{array}$ & $\begin{array}{c}\text { Most } \\
\text { common } \\
\text { sign }\end{array}$ & $\begin{array}{c}\text { 2nd } \\
\text { most } \\
\text { common } \\
\text { sign }\end{array}$ \\
\hline 1 & $\begin{array}{l}\text { Keisu et al } \\
\text { (1990) }\end{array}$ & $\begin{array}{l}\text { Israel } \\
\text { And } \\
\text { Euro Pe }\end{array}$ & 100 & $\begin{array}{c}\text { Neoplastic } \\
\text { diseases and } \\
\text { radiation }[32 \%]\end{array}$ & $\begin{array}{c}\text { Aplastic } \\
\text { anemia[ } 19 \%]\end{array}$ & - & - & - \\
\hline 2 & $\begin{array}{l}\text { Khodke et } \\
\text { al (2002) }\end{array}$ & India & 50 & $\begin{array}{c}\text { Megaloblastic } \\
\text { Anemia } \\
{[44 \%]}\end{array}$ & $\begin{array}{c}\text { Aplastic } \\
\text { anemia[14\%] }\end{array}$ & - & - & - \\
\hline 3 & $\begin{array}{l}\text { Seema B et al } \\
(2006)\end{array}$ & India & 137 & $\begin{array}{c}\text { Megaloblastic } \\
\text { Anemia } \\
{[56.9 \%]}\end{array}$ & $\begin{array}{c}\text { Aplastic } \\
\text { anemia[9.4\%] }\end{array}$ & - & - & - \\
\hline 4 & $\begin{array}{c}B \text { N Gayathri et } \\
a(2005-07)\end{array}$ & India & 104 & $\begin{array}{c}\text { Megaloblastic } \\
\text { Anemia } \\
{[74 \%]}\end{array}$ & $\begin{array}{c}\text { Aplastic } \\
\text { Anemia } \\
{[18.26 \%]}\end{array}$ & $\begin{array}{c}\text { Generalised } \\
\text { weakness } \\
{[100 \%]}\end{array}$ & $\begin{array}{c}\text { Pallor } \\
{[100 \%]}\end{array}$ & $\begin{array}{c}\text { Fever } \\
{[38.46 \%]}\end{array}$ \\
\hline 5 & $\begin{array}{c}\text { Santra B et al } \\
\text { (2010) }\end{array}$ & India & 111 & $\begin{array}{c}\text { Aplastic anemia } \\
{[20.7 \%]}\end{array}$ & CLD[ $11.7 \%]$ & $\begin{array}{c}\text { Generalised } \\
\text { Weakness } \\
{[50 \%]}\end{array}$ & $\begin{array}{c}\text { Generalised } \\
\text { Weakness } \\
{[50 \%]}\end{array}$ & $\begin{array}{c}\text { Splenom } \\
\text { egaly } \\
{[44.14 \%]}\end{array}$ \\
\hline 6 & $\begin{array}{l}\text { Doshi D et } \\
\text { al(2011) }\end{array}$ & India & 100 & $\begin{array}{c}\text { Megaloblastic } \\
\text { anemia } \\
{[45 \%]}\end{array}$ & $\begin{array}{c}\text { Infectious[20 } \\
\%]\end{array}$ & $\begin{array}{c}\text { Lethargy } \\
\text { [70\%] }\end{array}$ & $\begin{array}{l}\text { Pallor } \\
{[100 \%]}\end{array}$ & Bleeding \\
\hline 7 & $\begin{array}{c}\text { Vandana } \\
\text { Raphael et al } \\
(2007-09)\end{array}$ & India & 80 & $\begin{array}{c}\text { Megaloblatic } \\
\text { anemia }[41.2 \%]\end{array}$ & $\begin{array}{l}\text { Aplastic } \\
\text { anemia } \\
{[8.7 \%]}\end{array}$ & - & $\begin{array}{c}\text { Pallor } \\
{[100 \%]}\end{array}$ & $\begin{array}{c}\text { Fever } \\
{[42.5 \%]}\end{array}$ \\
\hline 8 & $\begin{array}{c}\text { Bhaskar B et } \\
\text { al(2011) }\end{array}$ & India & 100 & $\begin{array}{c}\text { Megaloblastic } \\
\text { Anemia } \\
{[37 \%]}\end{array}$ & Malaria [19\%] & - & $\begin{array}{c}\text { Pallor } \\
{[100 \%]}\end{array}$ & $\begin{array}{c}\text { Splenom } \\
\text { egaly } \\
{[70 \%]}\end{array}$ \\
\hline 9 & $\begin{array}{l}\text { In our study } \\
\text { (2013) }\end{array}$ & India & 102 & $\begin{array}{c}\text { Megaloblastic } \\
\text { anemia [43.1\%] }\end{array}$ & $\begin{array}{l}\text { Aplastic } \\
\text { Anemia } \\
{[19.6 \%]}\end{array}$ & $\begin{array}{c}\text { Easy } \\
\text { fatiguability } \\
{[98 \%]}\end{array}$ & $\begin{array}{c}\text { Easy } \\
\text { fatiguability } \\
{[98 \%]}\end{array}$ & $\begin{array}{c}\text { Fever } \\
{[35.29 \%]}\end{array}$ \\
\hline
\end{tabular}

SLE is another important etiology in our study, seen in 4 out of 102 subjects and all of them were females. Bone marrow may be target organ in SLE [20]. Pereira et al studied 21 patients of SLE with peripheral cytopenia, on bone marrow biopsy they found global hypocellularity and increased reticulin proliferation as the commonest finding. [20] Drug induced pancytopenia should be considered and a detail drug history should be elicited. 
Common over the counter drugs like ibuprofen can also cause pancytopenia. Organophosphorus exposure, cytotoxic drugs, chloramphenicol, methotrexate, phenytoin are commonly implicated [21].

Pancytopenia in Indian setting is mostly due to benign because mainly megaloblastic anemia secondary to B12 deficiency caused either by dietary deficiency or treatable condition for example tuberculosis. Emphasis on dietary awareness and supplements wherever required may thus reduce the incidence of pancytopenia and related problems.

Funding: Nil, Conflict of interest: None initiated,

Permission from IRB: Yes

\section{References}

1. Williams DM. Pancytopenia, aplastic anemia and pure red cell aplasia. Wintrobe's Clinical Hematology. 1999;9:911-43.

2. Tilak V, Jain R. Pancytopenia--a clinico-hematologic analysis of 77 cases. Indian J Pathol Microbiol. 1999 Oct; 42(4):399-404.

3. Khodke K, Marwah S, Buxi G, Yadav RB, Chaturvedi NK. Bone marrow examination in cases of pancytopenia. Journal, Indian Academy of Clinical Medicine. 2001Jan-June. 2001;2: 1-2.

4. Incidence of aplastic anemia: the relevance of diagnostic criteria. By the International Agranulocytosis and Aplastic Anemia Study. Blood. 1987 Dec;70 (6):1718-21.

5. Keisu M, Öst $\AA$. Diagnoses in patients with severe pancytopenia suspected of having aplastic anemia. European journal of haematology.1990Jul 1;45(1):11-4.

6. Bijjaragi S, Kulkarni VG, Belagatti SL, Kadam SS. Clinico-Hematological Profile of Pancytopenia in North Karnataka-One Year Study. Indian Journal of Public Health Research \& Development. 2013 Apr 1;4(2):234.

7. Gayathri BN, Rao KS. Pancytopenia: a clinico hematological study. J Lab Physicians. 2011 Jan;3(1): 15-20. doi: 10.4103/0974-2727.78555.

8. Doshi D, Shah AN, Somani S, Jain A, Jivarajani H, Kothari P. Study of clinical and aetiological profile of 100 patients of pancytopenia at a tertiary care centre in India. Hematology. 2012 Mar;17(2):100-5. doi: 10. 1179 / $102453312 X 13221316477976$.

9. Thakkar BB, Bhavsar UN, Trivedi NJ, Agnihotri AS. A study of pancytopenia in adult patients more than 12 years of age in North West region of saurashtra. Nat J Med Res. 2013;3(1):48-52.
10. Khanduri U, Sharma A. Megaloblastic anaemia: prevalence and causative factors. Natl Med J India. 2007 Jul-Aug;20(4):172-5.

11. Hesdorffer CS, Longo DL. Drug-Induced Megaloblastic Anemia. N Engl J Med. 2015 Oct 22;373 (17) : 1649 - 58. doi: 10. 1056 / NEJMra 150 8861.

12. A Victor Hoffband. Harrison's Principle of Internal Medicine 19th edition. New York: Mc Graw Hill Education; 2015 Chapter128, Megaloblastic anemias; p640-644.

13. Santra G, Das BK. A cross-sectional study of the clinical profile and aetiological spectrum of pancytopenia in a tertiary care centre. Singapore Med J. 2010 Oct;51(10):806-12.

14. Jain A, Naniwadekar M. An etiological reappraisal of pancytopenia-largest series reported to date from a single tertiary care teaching hospital. BMC Blood Disorders. 2013 Nov 6;13(1):1.

15. Killick SB, Bown N, Cavenagh J, Dokal I, Foukaneli T, Hill A, Hillmen P, Ireland R, Kulasekararaj A, Mufti G, Snowden JA, Samarasinghe $\mathrm{S}$, Wood $\mathrm{A}^{0}$, Marsh JC; British Society for Standards in Haematology. Guidelines for the diagnosis and management of adult aplastic anaemia. Br J Haematol. 2016 Jan;172(2):187-207. doi:10.1111/bjh.13853. Epub 2015 Nov 16.

16. Hamid GA, Shukry SA. Patterns of pancytopenia in Yemen. Turk J Haematol. 2008 Jun 5;25(2):71-4.

17. Dasgupta S, Mandal PK, Chakrabarti S. Etiology of Pancytopenia: An Observation from a Referral Medical Institution of Eastern Region of India. J Lab Physicians. 2015 Jul-Dec; 7(2):90-5. doi: 10.4103 / 0974-2727. 163136. 
18. Premkumar M, Gupta N, Singh T, Velpandian T. Cobalamin and folic Acid status in relation to the etiopathogenesis of pancytopenia in adults at a tertiary care centre in north India. Anemia. 2012;2012:707402. doi: 10.1155/2012/707402. Epub 2012 Apr 1.

19. Simmons CP, Farrar JJ, Nguyen vV, Wills B. Dengue. N Engl J Med. 2012 Apr 12;366(15):1423-32. doi: 10.1056/NEJMra1110265.
20. Pereira RM, Velloso ER, Menezes Y, Gualandro S, Vassalo J, Yoshinari NH. Bone marrow findings in systemic lupus erythematosus patients with peripheral cytopenias. Clinical rheumatology. 1998 May 1;17 (3):219-22.

21. Kar M, Ghosh A. Pancytopenia. J Indian Acad Clin Med. 2002 Jan;3(1):29-34.

\section{How to cite this article?}

Vaidya M, Gupta V. A, Khandagale S.K. Clinical Study of Pancytopenia. Int J Med Res Rev 2016;4(9):15511558.doi:10.17511/ijmrr.2016.i09.06. 